\title{
Motivational factors for engaging in dirty work entrepreneurship among a sample of African immigrant entrepreneurs in South Africa
}

\begin{tabular}{|c|c|}
\hline \multicolumn{2}{|c|}{$\begin{array}{l}\text { Authors: } \\
\text { Charles Cobbinah }^{1} \\
\text { Willie T. Chinyamurindi }\end{array}$} \\
\hline \multicolumn{2}{|c|}{$\begin{array}{l}\text { Affiliations: } \\
{ }^{1} \text { Department of Business } \\
\text { Management, University } \\
\text { of Fort Hare, South Africa }\end{array}$} \\
\hline \multicolumn{2}{|c|}{$\begin{array}{l}\text { Corresponding author: } \\
\text { Willie Chinyamurindi, } \\
\text { wchinyamurindi@ufh.ac.za }\end{array}$} \\
\hline \multicolumn{2}{|c|}{$\begin{array}{l}\text { Dates: } \\
\text { Received: } 08 \text { Dec. } 2017 \\
\text { Accepted: } 29 \text { May } 2018 \\
\text { Published: } 30 \text { Oct. } 2018\end{array}$} \\
\hline \multicolumn{2}{|c|}{$\begin{array}{l}\text { How to cite this article: } \\
\text { Cobbinah, C., \& } \\
\text { Chinyamurindi, W.T. (2018). } \\
\text { Motivational factors for } \\
\text { engaging in dirty work } \\
\text { entrepreneurship among a } \\
\text { sample of African immigrant } \\
\text { entrepreneurs in South Africa. } \\
\text { SA Journal of Human Resource } \\
\text { Management/SA Tydskrif vir } \\
\text { Menslikehulpbronbestuur, } \\
\text { 16(0), a1025. https://doi. } \\
\text { org/10.4102/sajhrm. } \\
\text { v16i0.1025 }\end{array}$} \\
\hline \multicolumn{2}{|c|}{$\begin{array}{l}\text { Copyright: } \\
\text { (C) 2018. The Authors. } \\
\text { Licensee: AOSIS. This } \\
\text { is licensed under the } \\
\text { Creative Commons } \\
\text { Attribution License. }\end{array}$} \\
\hline \multicolumn{2}{|l|}{ Read online: } \\
\hline 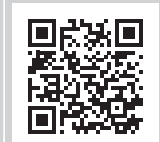 & $\begin{array}{l}\text { Scan this QR } \\
\text { code with your } \\
\text { smart phone or } \\
\text { mobile device } \\
\text { to read online. }\end{array}$ \\
\hline
\end{tabular}

Orientation: South Africa is witnessing a large number of African immigrants coming into the country. These immigrants seek formal and informal employment. One sector favoured is 'dirty work' within the informal sector.

Research purpose: To investigate the immigrants' motivational factors influencing migration and dirty work entrepreneurship in South Africa.

Motivation for the study: Because of the dynamic nature of political and economic circumstances that affect a country's employment options, calls have been made for empirical focus on understanding the career development processes of neglected sample groups such as immigrants and even those engaged in dirty work.

Research approach/design and method: A qualitative research approach was utilised based on the narratives and stories of 27 immigrant entrepreneurs in the informal sector engaged in dirty work careers.

Main findings: Three narratives emerged as motivating factors for migrating: (1) socioeconomic issues, (2) lack of opportunities and (3) experience of a new life. Furthermore, three motivational factors led into dirty work careers: (1) challenges of breaking into formal employment because of immigration rules, (2) motivation from social networks the immigrants belong to and (3) an enterprising spirit, driven by ambition.

Practical/managerial implications: Based on the findings, interventions can be proposed to assist not only those engaged in dirty work but also migrants and citizens seeking opportunities in this sector.

Contribution/value add: This study advances the literature in dirty work research within a South African context. Further, the study gives currency to an often neglected yet important sample group in dirty work entrepreneurship, who also happen to be immigrants.

\section{Introduction}

Small, micro and medium enterprises (SMMEs) offer great economic value in alleviating poverty (Charman, Petersen, Piper, Liedeman, \& Legg, 2017; Peberdy \& Rogerson, 2000). Within these enterprises are careers classified as 'dirty work' because of the association taint and precarious connotations that accompany them (Ashforth, Kreiner, Clark, \& Fugate, 2017; Budlender \& Fauvelle-Aymar, 2014; Hughes, 1958). Informal sector careers such as hairdressing, shoe repairing, vulcanising, masonry and others fall under physical and social dirty work (Ashforth \& Kreiner, 2014). As an international trend, South African society perceives dirty work as undesirable and therefore extends the perceived dirty nature of the work to the people who perform it (Ashforth \& Kreiner, 2014; Bickmeier, Lopina, \& Rogelberg, 2014; Crush, 2011). The associated social stigmatisation devalues both formal and informal sector dirty workers and fosters an inferiority complex (Ashforth et al., 2017; Berkelaar, Buzzanell, Kisselburgh, Tan, \& Shen, 2012).

Dirty work careers offer opportunities for a significant number of African immigrants (Hart \& Acs, 2011; Vinogradov \& Jorgensen, 2017). However, in South Africa, this category of immigrants who are not in the formal sector is stratified and stigma is affixed to them (Crush, 2000; Peberdy \& Rogerson, 2000). Therefore immigrants choosing stigmatised career paths suggest underlying motives influencing these choices. Despite the rise in immigrant dirty work entrepreneurship (e.g. Fatoki \& Patswawaire, 2012; Kalitanyi \& Visser, 2010), notably 
little research within a South African context exists. This research seeks to respond to these calls made and contribute towards immigrants' career development processes (Crush, 2017; Greyling, 2016).

\section{Research purpose and objective}

The study explored immigrants' motivational factors in migrating and entrance into dirty work careers in the Eastern Cape Province of South Africa. This became relevant in the following ways. Foremost, dirty work is known to exist and hence such unusual but crucial careers ought to be performed just as mainstream labour (Ashforth \& Kreiner, 2014; Miller \& Breton-Miller, 2017). In the case of South Africa, Budlender and Fauvelle-Aymar (2014) report that the percentage of immigrants working in the informal sector (where dirty work persists) is almost twice as high as that of citizens. All this supports the arguments for the need to understand the economic gains and important roles played by immigrants in the host country (Neves \& Du Toit, 2012; Van den Bergh \& Du Plessis, 2012). Secondly, South Africa is currently the largest economy in Africa but it has its own share of unskilled, undereducated and unemployed black and mixed-race citizens whose formal sector prospects are impacted (Broussard, 2017; Statistics South Africa, 2017). Within these groups, those without matric (Grade 12) constitute more than $58 \%$ of the unemployment rate (Stats SA, 2013). These citizens may experience socio-economic conditions and hardships often synonymous with immigrants (Broussard, 2017).

Further, the South African informal sector economy has an insignificant impact on the economic development agenda (Charman et al., 2017). There is general lack of interest and readiness to work in precarious working conditions (Budlender \& Fauvelle-Aymar, 2014). This may contribute to workforce shortages as well as the marginalisation of dirty workers (Berkelaar et al., 2012). Calls exist for the expansion of informal economic activities and entrepreneurship to stimulate economic growth in marginalised communities (Charman et al., 2017; Crush, 2011). However, the immigrants' dominance in the informal sector and settlements often result in severe hostility manifestations such as xenophobic attacks (Crush, 2000; Kalitanyi \& Visser, 2010), hence the need to identify and address factors that may affect the lived experiences of dirty workers. The main research question guiding this study was: What factors (given the South African context) influence entry into the host country and dirty work entrepreneurship in the informal sector?

\section{Factors influencing immigrant movements}

This study uses a push-pull plus concept (Van Hear, Bakewell, \& Long, 2017) as one of its theoretical bases. It stresses the significance of different internal and external forces driving international mobility. Several studies have attempted to explain what factors push people out of their country and pull them towards another (Harry, Dodd, \& Chinyamurindi, 2017; Selmer \& Lauring, 2011; Van Hear et al., 2017). While push factors are internal drivers within the home country, pull factors are external within the host country. Individuals and the circumstances serving as their motivation for migration vary (Harry et al., 2017). It all depends on the type of individual, demographics, economics, political conditions, ethnicity, race and gender, among others (Pheko, 2014; Selmer \& Lauring, 2011).

Studies on skilled African expatriates cite worsening economic and political conditions and stagnant career development as the main push factors and the reverse of such conditions stability, security and better work environments - form pull factors for migrating (Harry et al., 2017; Van den Bergh \& Du Plessis, 2012). Generally, motivation for migrating from less developed countries to a more highly developed one includes escape from adverse situations for employment opportunities, financial success and life change (Harry et al., 2017; Selmer \& Lauring, 2011). Given the complexity surrounding push and pull drivers and growing theories, there are arguments for the need for more empirical research into modern-day African immigrants within the context of developing countries (Van Hear et al., 2017). Through this, the role played by motivational factors and their association with dirty work entrepreneurship could be established.

\section{Factors influencing immigrants' involvement in dirty work}

Two models are considered as influencing entry into dirty work. Firstly, the model of entrepreneurial careers (MEC) of Dyer (1994) and second, the model of challenge-based entrepreneurship (MCBE) by Miller and Breton-Miller (2017). In the MEC, career socialisation and the antecedents that influence career choice address immigrants' career dynamics and dilemmas. The antecedents (individual, social and economic) are classified by Dyer (1994) as factors that influence an entrepreneur's career decision-making. Similarly, in the MCBE, four aspects play a role in immigrants' entrepreneurship journey. These are (1) the types of challenges such as socio-cultural, economic, cognitive, physical and emotional; (2) conditions and experiences; (3) adaptive requirements and (4) outcomes. Bridging these models suggests that experiences in struggling to overcome challenges in life may translate into a positive work attitude and discipline.

Dyer (1994, p. 10) notes that people from deprived homes marked with poverty and parental neglect become 'highly impulsive, reject authority figures, have persistent feelings of rejection and isolation'. This leads to inferior linguistic skills and cultural adaptation even if they migrate (AliagaIsla \& Rialp, 2012; Ruiz, Ibarreche, Peterson, \& Guerrero, 2017). On this subject, various literature links adverse economic factors to educational quality and one's ability to find acceptable employment (Bontis, Crossan, \& Hulland, 2002; Dimov, 2007). Additionally, immigrants often find themselves outside the mainstream labour markets because of work restrictions, local laws and various hiring practices (Bogan \& Darity, 2008; Hart \& Acs, 2011). This creates unemployment, a sense of loss and leads to unusual types of 
work or consideration of self-employment (Block, Kohn, Miller, \& Ullrich, 2015; Masurel, Nijkamp, Tastan, \& Vindigni, 2002; Minniti \& Nardone, 2006).

When the challenges become conditions, socialisation forms adaptive measures to compensate and reach an outcome (Dyer, 1994; Miller \& Breton-Miller, 2017). The need for engaging other individual entrepreneurs has been found as one of the means of seeking social learning in the opportunity development process (Dutta \& Crossan, 2005; Kautonen \& Palmroos, 2010). An immigrant may appeal to fellow immigrants for vocational aid and social support (Aliaga-Isla \& Rialp, 2012; Miller \& Breton-Miller, 2017). This gives an indication that life challenges and hardships may induce special entrepreneur conditions for coping with such circumstances.

\section{Research design \\ Research approach}

A qualitative research approach based on narratives and stories of individual participants was adopted. This approach brought about the deeper understanding of the immigrants' motivational factors in an expanded form. The strength of qualitative research in studies related to immigrants and entrepreneurship is the enhancement of participants' free flow and expression concerning the phenomenon understudy in their natural setting (Cohen, Manion, \& Morrison, 2011; Pheko, 2014). This allowed collection of relevant information from participants because stories 'act in people's lives in ways that matter deeply' (Smith, 2016, p. 202).

\section{Research strategy}

In-depth interviews with probing were conducted to allow individual participants to put their lived experiences in a narrative context for the attainment of the richest source of information (Smith, 2016). Interviewing helped in eliciting 'meaning-making' stories and reflections from those lived experiences and in understanding the rationale behind participants' responses (Chinyamurindi, 2016, 2017; Saldana, 2009).

\section{Research method}

\section{Sampling and participants}

Out of a group of African immigrant owners in dirty work careers operating in East London, 27 participants (19 males and 8 females from 7 different countries) were selected to participate in the research. A non-probability sampling method with a snowball sampling technique was employed in selecting participants (Cohen et al., 2011). The following inclusion and exclusion criteria were used to select participants: (1) a participant had to be self-expatriated, (2) a participant had to establish his or her own dirty work business from scratch and (3) a participant had to be the one responsible for managing such a business. The criteria were further used by the key informants in the recruiting process.
This ensured consistency in the information gathered from the participants' experiences in dirty work. The participants' demographic characteristics are illustrated in Table 1.

\section{Data collection methods}

A carefully developed interview guide with open-ended questions was utilised for the interviews. Prior to every interview, the participants were briefed thoroughly and reassured of their rights and responsibilities in the participation in the research (Miles, Huberman, \& Saldana, 2014). The interviews were conducted at times and in places (mostly at the business premises) identified by the participants as convenient. The interviews were conducted between April 2017 and August 2017 and lasted a maximum of $63 \mathrm{~min}$.

\section{Recording of the data}

\section{Data analysis}

Completed transcriptions were imported to QSR NVivo Version 11 for better data management and analysis (Woods, Paulus, Atkins, \& Macklin, 2016). The three levels of meaning-making adopted from previous research (Chinyamurindi, 2016, 2017; Harry et al., 2017; Richards, 2015) formed the data analysis procedure. In Level 1 , an indwelling process started. Each interview was read and the audio recordings listened to multiple times to understand and connect participants' lived experiences in migration and dirty work (Smith, 2016; Toolis \& Hammack, 2015). Stories and structure were identified from the data. Level 2 helped to classify responses into meaningful categories where the factors, their meanings and quotes based on their consistencies across the stories narrated by the individual participants were identified (Chinyamurindi, 2016; Saldana, 2009). Level 3 helped to analyse the content of the narrative accounts gathered as well as the factors that served as themes (Richards, 2015; Saldana, 2009).

\section{Strategies to ensure data quality and reporting}

Strict guidelines were followed to ensure data quality and reporting. Firstly, an interview guide was designed and reviewed by experts and was piloted in the validation process. Secondly, data collection lasted for a 5-month period, which allowed a relaxed atmosphere with adequate researcher reflections and accurate transcription. Data collection stopped only when the researchers were convinced that data saturation was reached, whereby no new information was extracted from the analysis. The researchers checked and verified the factors that emerged to reduce subjectivity and optimise the validity of the analysis as well as the internal reliability of the research (Miles et al., 2014).

\section{Ethical considerations}

This research followed the institutional ethical requirements. Participants were served with letters and consent forms detailing the objectives, confidentiality issues and their right to participation (Miles et al., 2014). 
TABLE 1: Participant profiles.

\begin{tabular}{|c|c|c|c|c|c|}
\hline Participant (pseudonym) & Age & Country of origin & Years in South Africa & Highest level of education & Current career \\
\hline Amon & 36 & Zimbabwe & 11 & Technical college & Tree felling \\
\hline Seko & 45 & Ghana & 15 & Diploma in Education & Hairdressing \\
\hline Joe & 44 & Zimbabwe & 13 & Technical college & Carpentry \\
\hline Doe & 42 & Ghana & 13 & Highest national diploma & - \\
\hline Diana & 38 & Zambia & 14 & Grade 12 & Hairdressing \\
\hline Shan & 45 & Zimbabwe & 16 & Technical college & Rubble removals \\
\hline Akosua & 36 & Ghana & 7 & Highest national diploma & Hairdressing \\
\hline Victoria & 38 & Ghana & 8 & Grade 12 & Hairdressing \\
\hline Bless & 44 & Nigeria & 8 & Bachelor (honours) & - \\
\hline Isaac & 45 & Ghana & 17 & A level (matric) & Vulcanising \\
\hline Gabriel & 49 & Ghana & 19 & A level (matric) & Hairdressing \\
\hline Chanda & 37 & Zambia & 10 & Grade 11 & Hairdressing \\
\hline Thomas & 38 & Ghana & 12 & Grade 11 & Hairdressing \\
\hline Jefta & 42 & Malawi & 8 & Grade 12 & Masonry \\
\hline Prince & 33 & Ghana & 4 & Grade 9 & Carpentry \\
\hline Joseph & 38 & Mozambique & 12 & Grade 9 & Carpentry \\
\hline Jolyn & 36 & Zambia & 11 & Grade 12 & - \\
\hline Patricia & 51 & Ghana & 18 & Grade 9 & Hairdressing \\
\hline Silan & 45 & Cameroon & 15 & Grade 9 & - \\
\hline Moh & 46 & Nigeria & 15 & Diploma in Marine Studies & - \\
\hline Edem & 35 & Ghana & 4 & Technical school & Masonry \\
\hline Alice & 50 & Zambia & 18 & Grade 12 & - \\
\hline Dan & 42 & Ghana & 7 & Grade 9 & - \\
\hline Rosey & 38 & Ghana & 8 & Grade 9 & Hairdressing \\
\hline Alfred & 33 & Zimbabwe & 11 & Form 6 (matric) & Carpentry \\
\hline Ketana & 40 & Mozambique & 12 & Grade 12 & Rubble removal \\
\hline
\end{tabular}

\section{Research results and findings}

Drawing from the data analysis, two main findings emerged. While the first finding was the motivating factors for leaving the home country, the second was the motivation to enter into dirty work in the host country. Tables 2 and 3 present the summary of the findings.

\section{Motivating factors to migrate}

Table 2 presents the three considered motivational factors for migrating from the home country. The first two factors can be considered as push factors while the third one forms a pull factor.

The first factor, socio-economic issues, covers the home country's poor economy, poverty, parental and personal hardship, living and financial constraints. This factor was summed up as having influenced most of the participants' education and infringed on their competitive abilities and hence the decision for migrating (see Table 2 for illustrating quotes). The stories of two participants, Victoria and Alfred, can be cited as examples. For Victoria:

'I did finish senior secondary school (matric) and I passed very well but [had] no money to carry on, no opportunities for me. I became eager to travel; you know; my country is hard economically I needed to leave ...' (Victoria, female, hairdresser, Ghana)

To Alfred, experiencing hardships because of socio-economic issues coupled with inadequate skill was difficult to manage. He explained:
'Things were bad back home for me and my family ... I was facing severe challenges. There was no money, adequate food and resources and I was a bright guy but I couldn't pass form six very well. I didn't get a job back home and I knew that I can get a job when I come to South Africa ...' (Alfred, male, carpenter, Zimbabwe)

A second factor motivating participants' decision to migrate was the lack of comparable opportunities especially in the area of jobs and remuneration (more quotes in Table 2). Although some of the participants cited that they were not idle in the home country, most of them perceived better achievements abroad. One participant, Chanda, despite working as a professional hairdresser, felt the limitation in such career and hence sought to relive her shattered dreams elsewhere. In her narration she mentioned:

'In my country those who have [become] established already are fine but some of us who were in the informal business like hairdressing - it's not easy, it [is] just struggling and hand to mouth affairs ... so it was difficult to make it big with this hairdressing there.' (Chanda, female, hairdresser, Zambia)

In addition to the two identified factors contributing to participants' decision to migrate, the need for a new life experience outside their home country was cherished.

'I decided to travel because my petty trading business wasn't meeting my dream target. I knew there was no way to overcome all the difficulties and become somebody at home at that time ... I used to see those who come from abroad and how they were progressing in life so I was motivated; that is why I'm here and still forcing [myself] to work hard to succeed.' (Kentana, male, rubble removals, Mozambique) 
TABLE 2: Motivating factors for leaving home country.

\begin{tabular}{|c|c|c|}
\hline Factor & Meaning & Illustrating quotes \\
\hline \multirow[t]{4}{*}{$\begin{array}{l}\text { Socio-economic } \\
\text { issues }\end{array}$} & \multirow{4}{*}{$\begin{array}{l}\text { Financial constraints, } \\
\text { home country } \\
\text { economic conditions, } \\
\text { schooling challenges }\end{array}$} & $\begin{array}{l}\text { 'I dropped out of school due to financial matters and hardship ... I hustle to support my parents and siblings so I had to move to SA.' } \\
\text { (Thomas, Ghana) }\end{array}$ \\
\hline & & $\begin{array}{l}\text { 'I had some difficulties back home as I was growing up since my parents struggled to look after us. Even school, I stopped along the } \\
\text { way because of financial and economic problems.' (Chanda, Zambia) }\end{array}$ \\
\hline & & $\begin{array}{l}\text { 'I [travelled] because the economic situation in my country was bad. I couldn't raise money to start my own business so I always } \\
\text { wanted to travel.' (Amon, Zimbabwe) }\end{array}$ \\
\hline & & $\begin{array}{l}\text { 'I was not educated because my father was not able to afford fees and at the same time look after us all (siblings) ... and how can } \\
\text { I compete with those who have the degrees. I had to find my way out in another country.' (Silan, Cameroon) }\end{array}$ \\
\hline \multirow[t]{3}{*}{$\begin{array}{l}\text { Lack of } \\
\text { opportunities }\end{array}$} & \multirow{3}{*}{$\begin{array}{l}\text { Unemployment, } \\
\text { difficulty in finding } \\
\text { a job in home country, } \\
\text { low pay }\end{array}$} & $\begin{array}{l}\text { 'I was [impatient] because when I finished my degree I was not finding a job and it was about whom you know so I decided to travel.' } \\
\text { (Bless, Nigeria) }\end{array}$ \\
\hline & & $\begin{array}{l}\text { 'I was just helping builders to park their materials and I get some tips (money). So I wasn't doing anything important back home. } \\
\text { No job, so things were difficult for me.' (Joseph, Mozambique) }\end{array}$ \\
\hline & & $\begin{array}{l}\text { 'Since I finished my secondary schooling, I spent about } 10 \text { years just assisting in my parents' business without finding any job } \\
\text { elsewhere. I learnt hairdressing work but I couldn't open my own shop. So I struggled all those years.' (Alice, Zambia) }\end{array}$ \\
\hline \multirow[t]{4}{*}{$\begin{array}{l}\text { Experience a } \\
\text { new life abroad }\end{array}$} & \multirow[t]{4}{*}{$\begin{array}{l}\text { Desire to turn } \\
\text { life around }\end{array}$} & $\begin{array}{l}\text { 'I wanted to travel to make my life better since [the] economic situation was tough and opportunities were not really there for some } \\
\text { of us.' (Prince, Ghana) }\end{array}$ \\
\hline & & $\begin{array}{l}\text { 'I found out that I can do better by making more money in [a] hair salon here than in my own country. I knew the economic situation } \\
\text { [was] better than back home so my aim was to prosper.' (Diana, Zambia) }\end{array}$ \\
\hline & & $\begin{array}{l}\text { 'I wanted to explore new ground and rebuild my future. Being a teacher in Ghana was no longer rewarding due to [the] economic } \\
\text { situation.' (Kennit, Ghana) }\end{array}$ \\
\hline & & $\begin{array}{l}\text { 'After many years of hustling on the street with nothing much to show, I felt [like] crossing the border to turn my situation around. } \\
\text { That was exactly what I did in [the] year 2005. At one point [a] man [needs a] bold step to save [his] future.' (Kentana, Mozambique) }\end{array}$ \\
\hline
\end{tabular}

TABLE 3: Motivational factors for dirty work.

\begin{tabular}{|c|c|c|}
\hline Factors & Meaning & Illustrating quotes \\
\hline \multirow[t]{3}{*}{$\begin{array}{l}\text { Document } \\
\text { constraints }\end{array}$} & \multirow{3}{*}{$\begin{array}{l}\text { Delays in permit } \\
\text { issuing, not meeting } \\
\text { requirements }\end{array}$} & $\begin{array}{l}\text { 'When I came I noticed that because of documentation and its requirements I wasn't going to get a soccer team soon, so I started } \\
\text { working in a salon.' (Seko, Ghana) }\end{array}$ \\
\hline & & $\begin{array}{l}\text { 'I can say lack of work permit was the first reason I decided to learn this mason job. When I came I needed a job badly to survive ... } \\
\text { but when they explained the permit requirements and processes, I became discouraged and I opted to learn [masonry] rather.' } \\
\text { (Jefta, Malawi) }\end{array}$ \\
\hline & & $\begin{array}{l}\text { 'I had problems with paper [documents] so I was advised to do hair since that was immediate work I can easily do without paper.' } \\
\text { (Victoria, Ghana) }\end{array}$ \\
\hline \multirow{3}{*}{$\begin{array}{l}\text { Social support } \\
\text { seeking and } \\
\text { acceptance }\end{array}$} & \multirow{3}{*}{$\begin{array}{l}\text { Reliant on established } \\
\text { immigrants for skills } \\
\text { and jobs }\end{array}$} & 'I learned this job here through my [countrywoman] I approached for help and she agreed to work with me.' (Jolyn, Zambia) \\
\hline & & $\begin{array}{l}\text { 'I did not go to plumbing school to know it. I did learn the practicals by assisting and observing and being trained by my boss.' } \\
\text { (Mohammed, Nigeria) }\end{array}$ \\
\hline & & $\begin{array}{l}\text { 'I started working at the salon; although I knew nothing about salon work, I had no paper and no money ... I needed to survive ... } \\
\text { so when I went to my [countrywoman] to accept me and teach me with salon skills, she agreed ...' (Prince, Ghana) }\end{array}$ \\
\hline \multirow[t]{3}{*}{$\begin{array}{l}\text { Enterprising } \\
\text { spirit }\end{array}$} & \multirow{3}{*}{$\begin{array}{l}\text { Desire to earn, low } \\
\text { level of contentment, } \\
\text { urgency in success }\end{array}$} & $\begin{array}{l}\text { 'You don't get what you want when you work for a company as a carpenter. It's better to be self-employed as it was in my case.' } \\
\text { (Joe, Zimbabwe) }\end{array}$ \\
\hline & & $\begin{array}{l}\text { 'I was paid the same amount as starters despite being a professional so I was looking forward to [having] enough savings to quit and } \\
\text { start my own business.' (Chanda, Zambia) }\end{array}$ \\
\hline & & $\begin{array}{l}\text { 'When I became perfect I was employed fully although I never thought I [would] be doing ladies' hair ... I became the key worker } \\
\text { doing all sort of hairstyles and managing affairs, but I was paid less, making it difficult for me to offer support to my families back } \\
\text { home so I had to open my own salon.' (Gabriel, Ghana) }\end{array}$ \\
\hline
\end{tabular}

In addition to the illustrating quotes (Table 2) and that of Kentana, the desire to make life better in the host country to compensate for the impacts of experienced socio-economic hardship became a motivational source for migrating.

The study also focused on the motivation for indulging in dirty work entrepreneurship.

\section{The immigrants' motivational factors in becoming dirty work entrepreneurs}

The challenge of breaking into formal employment because of immigration rules became a route to dirty work entrepreneurship. Although prior to migration, some participants anticipated finding jobs in the formal sector, informal sector dirty work became a career option. This was because of lack of meeting work permit requirements or failure to attain documentation on time (illustrating quotes in Table 3). For example, Bless, with his honours degree, had the prospect of finding a befitting job affected. As stated below:
'When I came, acquiring a document became a problem as the policies were changed so often. As things were delayed, I opted to enter into the informal sector and work in the salon rather for the time being while sorting out my documentation ... I was thinking I was going to get a job as a banker, teacher or manager in a company but none came my way because of documents delay ...' (Bless, male, hairdresser, Nigeria)

This factor influenced the participants' plans, perceptions about careers and their stigma as well as entrepreneurship intentions and behaviours. The story of Prince appears to reveal this:

'I became stranded in a way since I needed to sort out my documentation and at the same time needed money to survive ... By the look of things, I found that documentation was a problem as per requirements, a company needs to have your work permit of which at that time I was not having but I knew ... I can manage my own small business in the informal sector. I will say I might have entered into the formal sector if I had the document ...' (Prince, male, carpenter, Ghana) 
The second motivating factor emanated from the social networks immigrants belong to (more quotes in Table 3). Newer immigrants sought support in the form of jobs and skills from the established ones. In return, the established immigrants accepted such requests. The participants (except one) attributed dirty work career involvement to this factor. For example, Joseph arrived without a certificate, skill or capital and lacked valid documents; despite this he turned into a dirty work entrepreneur through others. He explains:

'When I came to South Africa in 2005, I joined other foreigners who were doing these jobs already so they took me and taught me how to do [these] carpentry and tiling jobs ... I spent about one year three months for carpentry and tiling took me about six months. I then worked with these artisans before I left ... Besides that, there was nothing immediate for me to do since I was not having documents.' (Joseph, male, carpenter, Mozambique)

Similarly, Patience, despite being a professional hairstylist before migrating, still had to connect and depend on established immigrants for support. She narrated:

\begin{abstract}
'I was a professional hairdresser already ... It's just that nobody comes with capital to start a business. So that was why I worked with somebody to get some money to buy the needed tools to start my own salon business ... So I worked for someone for a while to get a paper and also to know the market and how things work here.' (Patience, female, hairdresser, Ghana)
\end{abstract}

Finally, an enterprising spirit driven by ambition (further quotes in Table 3) was a motivating factor paving the way to dirty work entrepreneurship. In all cases, despite being accepted at a place of work at a time of need, participants were still sceptical and eager to break out and establish their own careers. Amon put it succinctly:

'When I came, I started working as a chef but in a small business and the salary was not good enough for me to survive. So I left and started working in a construction industry. The pay was not much ... Then my Uncle employed me in his tree felling business ... I started doing all the jobs but he pays me little portion, so I said to myself, why can't I do my own thing to be my own boss? So I bought one machine to start with.' (Amon, male, tree felling, Zimbabwe)

Drawing from the strong desire to succeed in the host country, in some instances, participants such as Prince relied on income analysis discourse as a measure to influence the rationale to become self-employed. He said:

'I started from the salon working for somebody but I felt that I was underpaid and cheated in a way. I did my own analysis from the income we were generating at the salon and how much I was paid, so this motivated me to take the necessary steps to save and leave and set up my own business and utilise my main skill ...' (Prince, male, carpenter, Ghana)

Even participants such as Shan who had once had a formal job discontinued it because of the urgent zeal to succeed. He narrated:

'When art business was bad, I looked for employment in the formal sector as a driver, but there too the salary was not good so after two years I decided to be self-employed so that I can make something for myself. I didn't want to be addicted to this small monthly salary and job, because there could be retrenchment, or the business can collapse, and then I can get stuck in life ... So I started this rubble removals business in 2006.' (Shan, male, rubble removal, Zimbabwe)

The main motivating factor was the search for greater financial independence and individual economic stability en route to overturning past experiences of hardship. Hence, dirty work entrepreneurship forms part of their economic emancipation.

\section{Discussion \\ Outline of the findings}

This study investigated the motivating factors of African immigrants leaving their home countries for South Africa. These factors are as follows: (1) socio-economic issues, (2) lack of competitive opportunities and (3) the desire to experience a new life abroad. Their interactions, experiences and relationships with adverse circumstances in their home country called for migration in order to redefine their life. The motivating factors for being involved in dirty work career entrepreneurship are (1) problems with immigration paperwork, (2) social network involvement and (3) an enterprising spirit. Thus, the document challenges encountered forced the participants to make use of their social networks and the need to be independent dirty work entrepreneurs was drawn from ambitious enterprising spirit. Although the former factors served as push factors for leaving home countries and the later formed the pull factors for being dirty workers in the host country, great challenges formed part of the immigrants' successful stories in adaptability.

\section{Relating main findings to the literature}

In this study, the adverse socio-economic conditions experienced by the participants influenced the decision to migrate, and this is consistent with previous studies. People, especially those from less developed countries, migrate to disassociate themselves from challenges faced in the home country (Harry et al., 2017; Van den Bergh \& Du Plessis, 2012). However, political factors were not considered as a push factor by the participants, as they were by skilled immigrants (Harry et al., 2017); rather the participants emphasised the role of perceived poor economic status in their home countries coupled with socio-economic hardships. This factor also contributed to educational constraint (Bontis et al., 2002) as many participants failed to realise their educational potential. The lack of opportunities also topped up as a push factor (Van Hear et al., 2017). It reinforced participants' internal desires to self-migrate (Harry et al., 2017) and formed the roadmap for justifying the pull factors from the host country. This confirms prior findings that employment, financial and improved living prospects motivate immigrants to migrate (Harry et al., 2017; Selmer \& Lauring, 2011). 
As demonstrated in previous studies, the lack of work permits excluded and restricted the participants from formal jobs (Bogan \& Darity, 2008; Minniti \& Nardone, 2006). Perhaps this is because the sample generally was unskilled immigrants. However, in this study, permits were not a prerequisite for hiring by established immigrant managers, through whom the participants were absorbed into informal sector dirty work careers. This is well supported by studies that place unemployment and illegality among the primary factors of immigrants becoming entrepreneurs out of necessity (Block et al., 2015; Bontis et al., 2002).

In line with the literature, the social networks provided immigrants with informal training and learning (Aliaga-Isla \& Rialp, 2012), skill acquisition and enhancement (Kautonen \& Palmroos, 2010), employment and information sharing (Masurel et al., 2002; Ruiz et al., 2017). However, engagement with their social networks became a temporary mechanism for coping with challenges. Documentation shortfall, the inability to fit into corporate jobs because of inadequate skills and education and lack of initial capital to set up business in the informal sector influenced this association. In addition, because the social network was deemed as a last resort, the participants fully utilised the opportunities therein to develop their dirty work careers. According to theories, challenges faced in their home and host countries evoked action, shaped their attitude towards reality and forced them to meet those challenges with social networking and hard work (Dimov, 2007; Miller \& Breton-Miller, 2017).

For an immigrant to become an independent entrepreneur out of necessity requires an enterprising spirit (Block et al., 2015) solely driven by strong ambition. Uniquely to this study, the participants considered this factor to breed the breakout attributes driving their self-employment prospects. These attributes included vigorous analysis of (1) income and expenditure, (2) remuneration and work effort and (3) employment and stability, as well as positive jealousy (desire to reach the employer's position), discontentment and a sense of urgency regarding success. Their considerations accelerated the participants' motives for skill, knowledge and resource acquisition while employed so that they could then take on high risk endeavours in dirty work. These attributes might explain why immigrants dominate informal sector activities in the host country over citizens (Budlender \& Fauvelle-Armar, 2014). This current research adds that immigrants remain more dissatisfied as dirty work employees than by the associated distasteful nature of the employment; however, their satisfaction is restored when they become self-employed in dirty work.

\section{Practical implication}

Many countries, including developing ones, are experiencing an influx of unskilled and undereducated international immigrants (Fatoki \& Patswawairi; 2012; Vinogradov \& Jorgensen, 2017). However, they should not be viewed in a negative light but as a valuable human resource with a hidden talent for vital dirty work entrepreneurship. The immigrants lacked adequate skills, advanced educational qualifications, financial capital upon arrival and battled with barriers in the host country. However, from their account, within an average of three years, they advanced in dirty work careers. This valuable ability to deal with unwelcome situations may encourage citizens or immigrants seeking access to a new life.

Inspiration could be drawn from the immigrants' utilisation of social networks to learn, perfect skills and accumulate resources (Aliaga-Isla \& Rialp, 2012; Ruiz et al., 2017). In addition, the significance attached to dirty work employment irrespective of little remuneration and greater taint (Ashforth et al., 2017) with the aim of tapping it for informal learning opportunities is worth adapting. This is an essential factor for citizens without or with matric but with no skills or formal employment to consider.

The enterprising spirit as narrated could be used as an empowerment tool for breaking the circle of the 'once employed remained employed' attitude of some people. Importantly, having knowledge about the depth of constraints immigrants' experience, their resilience, strategies and motivations for overcoming such difficulties may equip people in similar circumstances. It may lead to alteration of hostile perceptions harboured against them and help to expand SMME economic activities in the informal sector (Charman et al., 2017).

As a heterogeneous group, immigrants require future research to deeply and widely look into their motivating factors for surviving in host countries without becoming homeless. With this, it could be established how this wealth of entrepreneurship characteristics became ingrained in this category of immigrants. This is essential because this research suggests that African immigrants fine-tune their innate entrepreneurship characteristics to easily adapt to dirty work careers in the host country.

\section{Limitations}

The findings of this research should be cautiously interpreted and applied but are not generalisable based on some limitations. Firstly, the sample consisted of immigrants (who happened to be unskilled) from only seven different African countries residing in South Africa, with varying cultural situations. Secondly, the dirty work businesses from which participants were selected were SMMEs with very few (involving five or fewer) employees, and those businesses varied in nature. Thirdly, only three locations in one town, mainly composed of African immigrant businesses, made up the demographic. Furthermore, only participants known to have established businesses and managed them by themselves were involved in the study.

\section{Conclusion}

Currently, because of advances in communication systems and human interactions, opportunities are easily spotted from abroad and this has led to migration between developed 
and developing countries. Many skilled or unskilled individuals can easily self-migrate. As a result, many unskilled and undereducated migrants have joined dirty work careers. However, research about this category of immigrants in this type of career is still limited. This study contributes to the understanding of the motivating factors underlying the decision to migrate and participate in dirty work entrepreneurship as a career path in South Africa. This research finding lays the basis for future research on immigrants and dirty work.

\section{Acknowledgements}

The authors thank all the participants of this study. Furthermore, the authors wish to thank the Govan Mbeki Research Development Centre at the University of Fort Hare for providing funding to conduct this study.

\section{Competing interests}

The authors declare that they have no financial or personal relationships that may have inappropriately influenced them in writing this article.

\section{Authors' contributions}

C.C. collected and analysed the data. He was responsible for writing the first two drafts of this paper. W.C. supervised C.C.'s postdoctoral fellowship. He also oversaw the data analysis and writing of the article.

\section{Funding}

Generous funding to conduct this study was provided by the Govan Mbeki Research Development Centre at the University of Fort Hare.

\section{References}

Aliaga-Isla, R., \& Rialp, A. (2012). How do information and experiences play a role in the discovery of entrepreneurial opportunities? The case of Latin-American immigrants in Barcelona. Latin American Review, 13, 59-80. https://doi.org/10. 1080/10978526.2012.675866

Ashforth, B. F., \& Kreiner, G. E. (2014). Dirty work and dirtier work: Differences in countering physical, social and moral taint. Management and Organisation Review, 10(1), 81-108. https://doi.org/10.1111/more.12044

Ashforth, B. E., Kreiner, G. E., Clark, M. A., \& Fugate, M. (2017). Congruence work in stigmatized occupations: A managerial lens on employee fit with dirty work. Journal of Organisational Behaviour, 38, 1260-1279. https://doi.org/10.1002/ job.2201

Bickmeier, R., Lopina, E. C., \& Rogelberg, S. G. (2014). Dirty work, well-being and performance. In M. Veldhovan \& R. Peccei (Eds.), Well-being and performance at work (pp. 1-16). London: Psychology Press.

Block, J., Kohn, K., Miller, D., \& Ullrich, K. (2015). Necessity entrepreneurship and competitive strategy. Small Business Economics, 44(1), 37-54. https://doi.org/ $10.1007 / \mathrm{s} 11187-014-9589-x$

Bogan, V., \& Darity, W. (2008). Culture and entrepreneurship? African American and immigrant self-employment in the United States. The Journal of Socio-Economics, 37(5), 1999-2019. https://doi.org/10.1016/j.socec.2007.10.010

Bontis, N., Crossan, M. M., \& Hullard, J. (2002). Managing an organizational learning system by aligning stocks and flows. Journal of Management Studies, 39(4), 437469. https://doi.org/10.1111/1467-6486.t01-1-00299

Broussard, N. H. (2017). Immigration and the labour market outcomes of natives in developing countries: A case study of South Africa. Economic Development and Cultural Change, 65(3), 389-424. https://doi.org/10.1086/690648

Budlender, D., \& Fauvelle-Aymar, C. (2014). Migration and employment in Southern Africa: Statistical and econometric analysis of internal and international migrants in statistics South Africa's labour market data. Migration for Work Consortium (MiWORC) Policy Brief, 6(2), 1-92.
Berkelaar, B. L., Buzzanell, P. M., Kisselburgh, L. G., Tan, W., \& Shen, Y. (2012). First, it's dirty. Second, it's dangerous. Third, it's insulting: Urban Chinese children talk about dirty work. Communication Monographs, 79(1), 93-114. https://doi.org/ about dirty work. Communication

Charman, A. J. E., Petersen, L. M., Piper, L. E., Liedeman, R., \& Legg, T. (2017). Smal area census approach to measure the township informal economy in South Africa. Journal of Mixed Methods Research, 11(1), 36-58. https://doi.org/10.1177/ 1558689815572024

Chinyamurindi, W. T. (2016). Using narrative analysis to understand factors influencing career choice amongst a sample of distance learning students in South Africa. South African Journal of Psychology, 46(3), 390-400. https://doi.org/10.1177/ 0081246315623662

Chinyamurindi, W. T. (2017). 'Mind the gap' - Experiences of previously disadvantaged individuals studying by distance learning: A case of selected UNISA students in the Eastern Cape. Progressio, 39(1), 34-48. https://doi.org/10.25159/0256-8853/1938

Cohen, L., Manion, L., \& Morrison, K. (2011). Planning educational research. Research methods in Education. New York: Routledge.

Crush, J. (2000). The dark side of democracy: Migration, xenophobia and human rights in South Africa. International Migration, 38(6), 103-123. https://doi.org/10.1111/ 1468-2435.00145

Crush, J. (2011). Complex movements, confused responses: Labour migration in South Africa. SAMP Policy Brief, 25, 1-27.

Crush, J. (2017). Informal migrant entrepreneurship and inclusive growth in South Africa, Zimbabwe and Mozambique. Cape Town; Southern African Migration Programme.

Dimov, D. (2007). Beyond the single-person, single-insight attribution in understanding entrepreneurial opportunities. Entrepreneurship Theory and Practice, 31(5), 713-731. https://doi.org/10.1111/j.1540-6520.2007.00196.x

Dutta, D. K., \& Crossan, M. M. (2005). The nature of entrepreneurial opportunities: Understanding the process using the 41 organizational learning framework. Entrepreneurship Theory and Practice, 29(4), 425-449. https://doi.org/10.1111/ Entrepreneurship Theory a
j.1540-6520.2005.00092.x

Dyer, W. G. (1994). Toward a theory of entrepreneurial careers. Entrepreneurship Theory and Practice, 19(2), 7-22. https://doi.org/10.1177/104225879501900202

Fatoki, O., \& Patswawairei, T. (2012). The motivations and obstacles to immigrant entrepreneurship in South Africa. Journal of Social Sciences, 32(2), 133-142.

Greyling, T. (2016). The expected well-being of urban refugees and asylum-seekers in Johannesburg. South African Journal of Economic and Management Sciences, 19(2), 232-248. https://doi.org/10.4102/sajems.v19i2.1317

Harry, T. T., Dodd, N. M., \& Chinyamurindi, W. T. (2017). Using narratives to understand the motivational factors and experience of being a self-initiated academic expatriate in South Africa. South African Journal of Human Resource Management, 15(0), a797. https://doi.org/10.4102/sajhrm.v15i0.797

Hart, D. M., \& Acs, Z. J. (2011). High-tech immigrant entrepreneurship in the United States. Economic Development Quarterly, 25(2), 116-129. https://doi.org/10.1177/ 0891242410394336

Hughes, E. C. (1958). Men and their work. Glencoe: Free Press.

Kalitanyi, V., \& Visser, K. (2010). African immigrants in South Africa: Job takers or job creators?. South African Journal of Economic and Management Sciences, 13(4), 376-390. https://doi.org/10.4102/sajems.v13i4.91

Kautonen, T., \& Palmroos, J. (2010). The impact of a necessity based start-up on subsequent entrepreneurial satisfaction. International Entrepreneurship and Management Journal, 6(3), 285-300. https://doi.org/10.1007/s11365-008-0104-1

Masurel, E., Nijkamp, P., Tastan, M., \& Vindigni, G. (2002). Motivations and performance conditions for ethnic entrepreneurship. Growth and Change, 33(2), 238-260. https://doi.org/10.1111/0017-4815.00189

Miles, M. B., Huberman, A. M., \& Saldana, J. (2014). Qualitative data analysis: A methods sourcebook. California: Sage.

Miller, D., \& Breton-Miller, I. (2017). Underdog entrepreneurs: A model of challengebased entrepreneurship. Entrepreneurial Theory and Practice, 41(1), 7-17. https://doi.org/10.1111/etap.12253

Minniti, M., \& Nardone, C. (2006). Ethnicity, immigration and entrepreneurial behaviour (Summary). Frontiers of Entrepreneurship Research, 26(12), Article 3. http://digitalknowledge.babson.edu/fer/vol26/iss12/3. Accessed: 13/03/17.

Neves, D., \& Du Toit, A. (2012). Money and sociality in South African informal economy, Africa, 82, 131-149. https://doi.org/10.1017/S0001972011000763

Peberdy, S., \& Rogerson, C. (2000). Transnationalism and Non-South African entrepreneurs in South Africa's Small, Medium and Micro-enterprise (SMME) economy. Canadian Journal of African Studies, 34(1), 20-40.

Pheko, M. M. (2014). Batswana female managers career experiences and perspectives on corporate mobility and success. South African Journal of Human Resource Management, 12(1), 1-11. https://doi.org/10.4102/sajhrm.v12i1.445

Richards, L. (2015). Handling qualitative data: A practical guide (3rd ed.). Dorchester: Sage.

Ruiz, M., Ibarreche, S., Peterson, L. T., \& Guerrero, L. (2017). The impact of immigrant acculturation and job search information on entrepreneurship opportunity. International Journal of Entrepreneurship and Small Business, 31(2), 288-308. https://doi.org/10.1504/IJESB.2017.10004853

Saldana, J. (2009). The coding manual for qualitative researchers. London: Sage.

Selmer, J., \& Lauring, J. (2011). Acquired demographics and reasons to relocate among self-initiated expatriates. International Journal of Human Resource Management, 22, 2055-2070. https://doi.org/10.1080/09585192.2011.580176 
Smith, B. (2016). 'Narrative analysis', in E. Lyons \& A. Coyle (Eds.), Analysing qualitative data in psychology (pp. 202-221). Thousand Oaks, CA: Sage.

Statistics South Africa. (2013). Quarterly Labour Force Survey: Quarter 2, 2013. Retrieved from http://microdata.worldbank.org/index.php/catalog/1634

Statistics South Africa. (2017). Quarterly Labour Force Survey: Quarter 1, 2017. Retrieved from http://statssa.gov.za/publications/PO211/PO2112ndQuartey2016.pdf

Toolis, E. E., \& Hammack, P. L. (2015). The lived experience of homeless youth: A narrative approach. American Psychological Association, 2(2), 50-68.

Van den Bergh, R., \& Du Plessis, Y. (2012). Highly skilled migrant women: A caree development framework. Journal of Management Development, 31(2), 142-158. https://doi.org/10.1108/02621711211199485
Van Hear, N., Bakewell, O., \& Long, K. (2017). Push-pull plus: Reconsidering the drivers of migration. Journal of Ethnic and Migration Studies, 44(6), 1-18. https://doi.org/ 10.1080/1369183X.2017.1384135

Vinogradov, E., \& Jorgensen, E. J. B. (2017). Differences in international opportunity identification between native and immigrant entrepreneurs. Journal of International Entrepreneurship, 15, 207-228. https://doi.org/10.1007/s10843016-0197-5

Woods, M., Paulus, T., Atkins, D. P., \& Macklin, R. (2016). Advancing qualitative research using qualitative data analysis software (QDAS)? Reviewing potential versus practice in published studies using ATAS. Ti and NVivo, 1994-2013. Social Science Computer Review, 34(5), 597-617. https://doi.org/10.1177/08944393 15596311 